\title{
A bioengineering approach for rational vaccine design towards the Ebola Virus
}

Sophia Banton ${ }^{*}$, Zvi Roth, Mirjana Pavlovic

From Sixth International Society for Computational Biology (ISCB) Student Council Symposium Boston, MA, USA. 9 July 2010

\section{Background}

The Ebolavirus (EBOV) is extremely lethal with mortality rates ranging from twenty-three to ninety percent. No licensed Ebola vaccine exists and classical protocols for vaccine design do not comply. One solution, rational vaccine design (RVD) is based on two parameters: (1.) identification of epitopes, antigenic peptides that mediate the cellular immune system and (2.) exploitation of the immune system's ability to recognize and remember vaccines.

\section{Methods}

To assess RVD feasibility, EBOV proteins were computationally analyzed for epitope identification. To evaluate vaccine efficacy, mathematical models for virus dynamics were simulated using MATLAB. Models relied on data

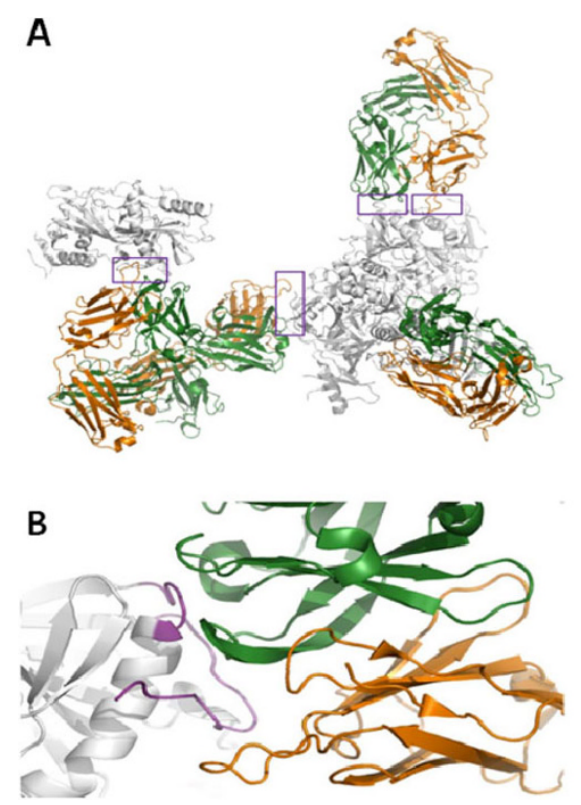

C

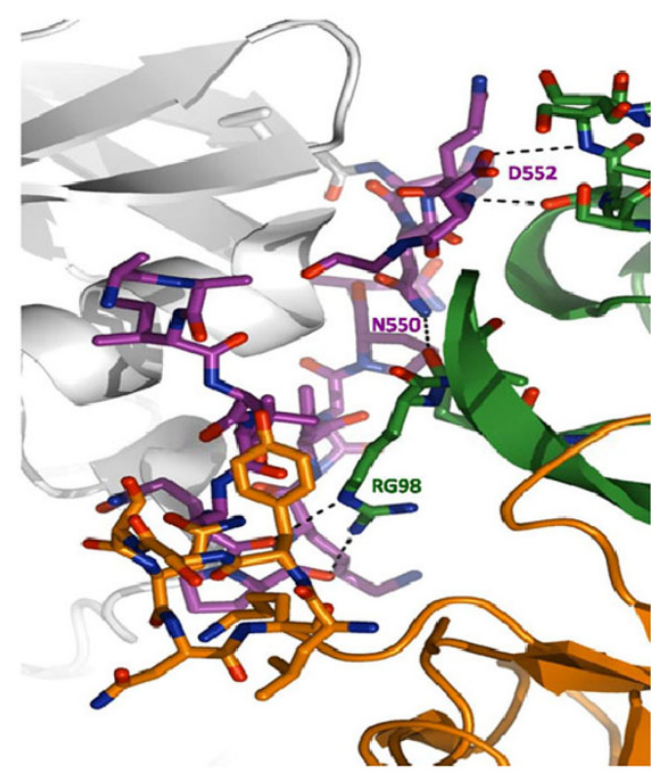

Figure 1 (A) The trimeric Ebola Virus glycoprotein (silver) interacts with the light (orange) and heavy (green) chains of human antibody KZ52. Purple boxes indicate sites of interactions, all of which are identical. (B) The EBOV GP epitope (purple) interacts with antibody loops at GP slits. (C) Salt bridges stabilize epitope-antibody binding. Salt-bridge measurements from top to bottom are $3.41 \AA$, $2.77 \AA$, $3.24 \AA$, $3.35 \AA$, and $2.90 \AA$.

* Correspondence: sophiabanton@yahoo.com

Department of Electrical Engineering (Bioengineering), Florida Atlantic

University, Boca Raton, FL 33431, USA 
from EBOV cultivation in cell-cultures, and were extended with novel equations to consider memory Band $\mathrm{T}$-cell production.

\section{Results}

First, RVD towards the EBOV is feasible. Computerbased protein analysis identified novel EBOV peptides for vaccine design. A key epitope -EAIVNAQPKCNPN... MHNQDG- was extracted from a three-dimensional structure of an EBOV protein bound to human antibody KZ52. Secondly, vaccine efficacy can be assessed using mathematical models. Multiple simulations of the models revealed generally unknown parameters such as the virus' birth and cellular infection rates. The models also quantified the cellular immune response necessary for vaccine efficacy in an individual; the specifications of what the vaccine must accomplish.

\section{Conclusion}

These results show that computer-aided RVD is feasible and that mathematical models can establish RVD guidelines for the development of an EBOV vaccine.

Published: 7 December 2010

\section{Reference}

1. Lee JE, Fusco M, Hessell AJ, Oswald WB, Burton DR, Saphire EO: Structure of the Ebola virus glycoprotein bound to an antibody from a human survivor. Nature 2007, 454(7201):177-183.

doi:10.1186/1471-2105-11-S10-O12

Cite this article as: Banton et al:: A bioengineering approach for rational vaccine design towards the Ebola Virus. BMC Bioinformatics 201011

(Suppl 10):012.
Submit your next manuscript to BioMed Central and take full advantage of:

- Convenient online submission

- Thorough peer review

- No space constraints or color figure charges

- Immediate publication on acceptance

- Inclusion in PubMed, CAS, Scopus and Google Scholar

- Research which is freely available for redistribution

Submit your manuscript at www.biomedcentral.com/submit 